\title{
Methomyl induced alteration in mice hepatic-oxidative status
}

Sudheer Manawadi and Kaliwal B.B. *

P.G. Department of Studies in Biotechnology and Microbiology, Karnatak University, Dharwad, 580003, India, *b_kaliwal@yahoo.com

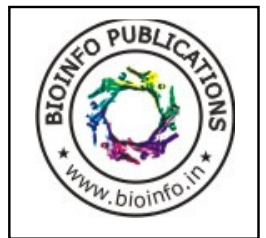

Abstract- Methomyl (S-methyl-1-N (methyl carbamoyl) oxy] thio acetimidate, is a $\mathrm{N}$-methyl carbamate broad spectrum insecticide. The methomyl containing technical formulation the "Lannate" was evaluated for its effects on the liver antioxidant contents, oxidative stress by-products and oxidative stress enzyme activities and histopathology in Swiss albino mice. Normal virgin male Swiss albino mice of 90 days old weighing about $25-30 \mathrm{~g}$ were used in the experiment. The mice were administered $1,2,3$, and $4 \mathrm{mg} / \mathrm{kg}$ body wt methomyl for 30 days and effective dose $4 \mathrm{mg}$ for 5,10 , and 20 days to know the dose and durational effect on liver. The mice were sacrificed on day $31^{\text {st }}$ or 24 hours after the terminal exposure. Liver dissected out freed from adherent tissue and weighed to nearest milligram. The liver histology, estimations of antioxidant contents, oxidative stress by-products and oxidative stress enzyme activities were carried out. Liver antioxidant contents showed that levels of GSH (Glutathione) and ascorbic acid were decreased significantly in mice treated with 2,3 and $4 \mathrm{mg} / \mathrm{kg} / \mathrm{day}$ methomyl and $4 \mathrm{mg} / \mathrm{kg} /$ day for 10 and 20days of methomyl treatment, except the level of ascorbic acid was not changed significantly in mice treated with $2 \mathrm{mg} / \mathrm{kg}$ body wt. Liver antioxidant products showed that levels of TBARS (thiobarbaturic acid) and protein carbonyl were increased significantly in mice treated with 2, 3 and $4 \mathrm{mg} / \mathrm{kg} /$ day methomyl and $4 \mathrm{mg} / \mathrm{kg} /$ day for 10 and 20days of methomyl treatment, except the level of TBARS was not changed significantly in mice treated with $2 \mathrm{mg} / \mathrm{kg}$ body wt of methomyl. Liver oxidative stress enzyme activities showed that levels of CAT (Catalase), SOD (super oxide dismutase) and GST (Glutathione-s-transferase) were decreased significantly in mice treated with 2, 3 and $4 \mathrm{mg} / \mathrm{kg} / \mathrm{day}$ methomyl and $4 \mathrm{mg} / \mathrm{kg} /$ day for 10 and 20days of methomyl treatment. The Histology of liver of mice treated with 2, 3 and $4 \mathrm{mg} / \mathrm{kg} /$ day methomyl and $4 \mathrm{mg} / \mathrm{kg} /$ day for 10 and 20days of duration showed that dilation of central vein, sinusoids between hypertrophied hepatocytes and cytoplasmic vacuolization with loss of radial arrangement of cells. The result of the present study suggests that chronic exposure to methomyl insecticide has deleterious effect on liver. The study also revealed that the methomyl might have affected cell metabolism and cell membrane permeability and detoxification system in liver.

Key words: Methomyl, Liver, Necrosis, GSH, TBARS, protein carbonyl, SOD.

\section{Introduction}

Pesticides are added to the environment for the purpose of killing or injuring some form of life. It is equally true that the majority of agrochemicals devoid of mutagenic activity and induce their effects by genotoxic or non genotoxic modes of action. In some cases the modes of action are known and they give a clear indication of the likely human hazards; in others, data are lacking or incomplete resulting in a more conservative approach towards human hazard and risk assessment [1]. Carbamate insecticides are widely used in agriculture and home gardening. They are derivatives of carbamic acid and like organophosphates, their mechanism of action is that of inhibiting the vital enzyme acetyl cholinesterase which is reversible as compared to organophosphates which is irreversible.[2] Exposure to cholinesterase inhibiting agents is considered a major health problem for the farm workers throughout the world. Methomyl is widely using throughout the world since it is effective as "contact insecticide" as well as "systemic insecticide".Methomyl has been classified as a pesticide of category-I toxicity [3]. Methomyl is a metabolite of thiodicarb and acetimidate is suspected oncogen which is metabolite in animal tissues [4]. Methomyl is endocrine disruptor and also potent genotoxic, capable of inducing structural and numerical chromosomal aberration in mammalian cells $[5,6]$. High incidence of acute poisonings was reported among patients exposed to a powder of methomyl [7-10]. Reports regarding methomyl effects on liver are very scanty. Hence present investigation was undertaken to elucidate the effects of methomyl on liver antioxidant system, oxidative stress enzymes and histopathology on albino mice.

\section{Materials and Methods}

\section{Animals}

Laboratory bred adult virgin female Swiss albino mice used in the experiments. Mice aged 90-120 days old weighing between 25$30 \mathrm{~g}$ was used. The mice were maintained in the P.G. Department of Studies in Zoology, Karnatak University, Dharwad. Mice breed quite normally, almost throughout the year and permitted through local ethical committee. They were housed in separate polypropylene cages containing sterile paddy husk as bedding material. The mice were provided with standard mice pellet diet "Gold Mohar" (Hindustan Liver 
Company, Mumbai) and water ad libitum. The mice were maintained under normal day/night schedule (12 L: $12 \mathrm{D})$ at room temperature 25 $\pm 2^{\circ} \mathrm{C}$.

\section{Chemical and Treatment}

Methomyl has CAS Registry Number 1675277-5.

$$
\text { Structural formula of methomyl }
$$<smiles>CS/C(C)=N\OC(=O)N(C)C</smiles>

The sample of methomyl (Lannate® $40 \%$ SP) used in experiments was commercial insecticide supplied by E.I. Dupont India Pvt. Ltd., Haryana obtained from the local company's market containing Methomyl (a.i) $40 \% \quad(\mathrm{w} / \mathrm{w})$, inert ingredient (silica) 6\%, embittering agent (sucrose octaacetate) $0.4 \%$, emulsifiable oil (sun spray $9 \mathrm{E}$ oil) $6.5 \%$, inert base (sucrose) $47.1 \%$. The doses were given orally in distilled water Vehicle, below their acute LD $\neg 50$ level of intoxication according to their body weight. The mouse oral LD50 for methomyl is found to be $10 \mathrm{mg} / \mathrm{kg}$ body weight [3]. The mice were administered $1 \mathrm{mg} ; 2 \mathrm{mg}, 3$ $\mathrm{mg}$, and $4 \mathrm{mg} / \mathrm{kg}$ body wt methomyl for 30 days and effective dose $4 \mathrm{mg} / \mathrm{kg}$ body wt for 5 days, 10 days and 20 days to know the dose and durational effect on liver. Control mice were received distilled water. All the mice were autopsied by cervical dislocation on day $31^{\text {st }}$, 24 hours after the last oral dose. The liver of all mice was dissected out and in each group 5 were processed for biochemical and remaining for Histopathological study.

\section{Oxidative stress parameters estimation}

Oxidative stress parameters such as estimations of GSH carried out as per the method described by Ellman [11], Ascorbic acid by Roe and Kuether [12], TBARS by Okhawa et al [13], protein carbonyl by Levine et al [14], Catalase by Aebi [15], SOD by Kakker et al [16], and GST by Habig and Jokoby [17] and Protein by Lowry et al [18].

\section{Histological studies}

For Histological study, fresh removed livers fixed in Bouin's fluid, dehydrated in ethanol and embedded in paraffin, and serial sections at 5 $\mu \mathrm{m}$ were prepared and stained with haematoxylin eosin.

\section{Statistical analysis}

Statistical significance between the control and experimental data were subjected to analysis of variance (ANOVA) together with Dunnett's test $(P<0.05)$.

\section{Results and Discussion}

Oxidative Stress parameters: The status of liver antioxidant, in mice treated with 2, 3 and 4 $\mathrm{mg} / \mathrm{kg} /$ day methomyl for 30 days and $4 \mathrm{mg} / \mathrm{kg} /$ day for 10 and 20 days of methomyl treatment caused significant decrease in the levels of GSH and ascorbic acid, except the level of ascorbic acid was not changed significantly in mice treated with $2 \mathrm{mg} / \mathrm{kg}$ body wt. However, treatment with $1 \mathrm{mg} / \mathrm{kg} /$ day and $4 \mathrm{mg} / \mathrm{kg} /$ day of methomyl caused no significant change in the levels of GSH and ascorbic acid when compared to control. In mice treated with 2, 3 and $4 \mathrm{mg} / \mathrm{kg} /$ day methomyl and $4 \mathrm{mg} / \mathrm{kg} /$ day for 10 and 20 days of methomyl treatment caused significant increase in the levels of TBARS and protein carbonyl, except the level of TBARS was not changed significantly in mice treated with $2 \mathrm{mg} / \mathrm{kg}$ body wt. However, treatment with $1 \mathrm{mg} / \mathrm{kg} /$ day and $4 \mathrm{mg} / \mathrm{kg} /$ day of methomyl caused no significant change in the levels of TBARS and protein carbonyl when compared to control. Liver oxidative stress enzyme activities showed that levels of CAT, SOD and GST were decreased significantly in mice treated with 2,3 and $4 \mathrm{mg} / \mathrm{kg} / \mathrm{day}$ methomyl and $4 \mathrm{mg} / \mathrm{kg} /$ day for 10 and 20 days of methomyl treatment. However, treatment with $1 \mathrm{mg} / \mathrm{kg} /$ day and $4 \mathrm{mg} / \mathrm{kg} /$ day of methomyl caused no significant change in the levels of CAT, SOD and GST when compared to control.

Histologic studies: The Histology of liver of mice treated with 2,3 and $4 \mathrm{mg} / \mathrm{kg} /$ day methomyl for 30 days and $4 \mathrm{mg} / \mathrm{kg} /$ day for 10 and 20 days of duration showed that dilation of central vein, sinusoids between hypertrophied hepatocytes and cytoplasmic vacuolization with loss of radial arrangement of cells. The control mouse liver showed radially arranged hepatic cords around the central vein and normal hepatocytes with centrally located nuclei.

In the present study with higher dose and prolonged duration of exposure to methomyl caused significant decrease in the levels of GSH and ascorbic acid in liver of mice. GSH is widely distributed tripeptide and found mainly in the cell cytosol [19]. Glutathione is the cell's natural antioxidant, which destroys free radicals formed in cells. This plays a crucial role in the detoxification process. GSH deficiency causes oxidant damage and greater lipid peroxidation which in turn leading to cell damage $[20,21,22]$. The mice treated intraperitoneally $7 \mathrm{mg} / \mathrm{Kg}$ body weight methomyl for one day promoted the oxidative damage of liver cells by enhancing peroxidation of membrane lipids $[23,24]$. Oxidative damage to excessive production of reactive oxygen species (ROS) has been associated with defective liver function due to its effect on cellular lipids, proteins and nucleic acids and carbohydrates 
[24, 25, 26, 27, 28,]. Significant depletion of GSH levels confirmed the potential of the methomyl to induce oxidative stress in hepatic tissue $[24,29]$.

Ascorbic acid is an important micronutrient necessary for a significant number of metabolic reactions in humans and other primates. Ascorbic acid is a potent water-soluble antioxidant that scavenges reactive oxygen species and reactive nitrogen species [30]. Ascorbic acid deficiency is characterized by increased oxidative stress and tissue injury resulting in inhibition of ascorbic acid biosynthesis $[31,32,33]$. In the present study high dose and prolonged exposure of methomyl caused decreased concentration of ascorbic acid. This may be due to increased production of ROS. It has been observed that methomyl treated rat erythrocytes and mouse liver caused increased level of lipid peroxidation due to production of ROS [24,34]. Recently it has been also reported that prolonged exposure of carbamate pesticides methomyl and carbosulfan resulted in accumulation of cholesterol in mouse liver and kidney $[27,28,35]$. This is direct evidence for deficiency of ascorbic acid due to oxidative stress as series of studies provided clear evidence that Ascorbic acid deficiency leads to reduced bile acid synthesis or catabolism of cholesterol due to decreased activity of the microsomal enzyme cholesterol 7a-hydroxylase [36]. Ascorbic acid is important for the hydroxylation of the cholesterol nucleus on $\mathrm{C} 7$. This reaction is catalyzed by the cholesterol 7a-hydroxylase and requires oxygen, NADPH, cytochrome p-450 and vitamin C. This reaction is inhibited by latent ascorbic acid deficiency and this leads to high concentration of cholesterol in the liver and the plasma $[37,38]$ and deficiency of ascorbic acid not only influences cholesterol or triglyceride concentrations but also integrity of vascular cells[39,40].

The present findings revealed that, an increase in high dose and prolonged exposure of methomyl showed increase in the concentration of lipid peroxidation. Lipid peroxidation (LPO) is a chain reaction between polyunsaturated fatty acids and ROS, and it produces lipid peroxides and hydrocarbon polymers that are both highly toxic to the cell. Malonyldialdehyde is an end product of peroxidation of polyunsaturated fatty acids and related esters, and is, therefore, used as a marker of lipid peroxidation. It has been reported that hydrogen peroxide treatment induced a significant increase in the lipid peroxidation and enhanced ROS generation. It has been observed that testicular damage caused by quinalphos was due to free radicalmediated by increased LPO [41]. It has been reported that chlorpyrifos, paraquat and diquat causes the oxidative stress with the increase in MDA in different tissues of rats $[42,43]$. Abdollahi et al. reported effects of malathion to oxidative stress and AchE activity in saliva and plasma in rats following subchronic exposure. Study results showed that malathion at doses of 100,500 , and $1500 \mathrm{ppm}$ increased plasma thiobarbituric acid reactive substances by 61 , 69, and 63\% [44].

Yarsan et al. [45] reported that aldicarb and malathion causes lipid peroxidation, indicating increased plasma MDA content in rodents. In another study of Yarsan et al. [46] the effects of delthamethrin on lipid peroxidation for subacute, subchronic, and chronic periods were investigated. Their study results indicated that MDA levels increased especially for the subchronic and chronic periods. Seth et al. [47] studied the effects of propoxur on lipid peroxidation. In that study they found that propoxur increased MDA levels and altered the glutathione levels. In another study Chlorpyrifos-induced oxidative stress and caused tissue damage in the liver, kidney, brain and fetus in pregnant rats, where there was increase in LPO, significant increase in TBARS, decrease in level of GSH and SOD in plasma and tissues and also caused significant fetal deaths [48]. Methomyl is also known to cause LPO in liver, kidney and erythrocytes [34]. In the present study the reason for increased MDA level under the influence of methomyl treatment in mice might be caused due to the conjugation of methomyl or its metabolites to the polyunsaturated fatty acids or by production of ROS reacts with polyunsaturated fatty acids or accumulation of liphophilic components of pesticides conjugated with the fatty acids.

The present findings revealed that, high dose and prolonged exposure of methomyl caused significant increase in the concentration of protein carbonyl. Among the various oxidative modifications of amino acids in proteins, protein carbonyl formation may be an early biomarker of ROS-mediated protein oxidation [49]. ROS known to modify or inactivate proteins in a variety of pathways [50,51]. Generally, ROS may cause reversible and/or irreversible modifications on sensitive proteins [51]. Reversible modifications, usually at cysteine residues, with dual role of protection from irreversible damage and modulation of protein function [50] Irreversible modifications induced by ROS such as carbonyl formation and accumulation of protein carbonyl by-products in tissues are generally associated with permanent loss of protein function, and are considered as indicator of severe oxidative damage and disease-derived from protein dysfunction [51]. ROS can react directly with the protein by oxidizing amino acid residue side-chains into ketone or aldehyde derivatives or they can react with molecules such as sugars and lipids, generating reactive carbonyl species that then can react with protein $[52,53]$. Zimmerman et al [54] reported that carbamate pesticide Thiocarbamate can form reactive sulfoxide and sulfone intermediates, which may be involved in the toxicity of thiocarbamates through covalent modification of cysteine and 
serine active sites of enzymes forming S- $(\mathrm{N}, \mathrm{N}$ Dialkylaminocarbonyl)cysteine adducts in rat brain, liver, and testes. It has been reported that exposure of Dieldrin induces oxidative damage in the mouse striatum, resulted in a $53 \%$ decrease in total glutathione, an increase in the redox potential of glutathione, and a $90 \%$ increase in protein carbonyls [55]. In another study, the effects of intraperitoneal injection of carbamate pesticide diethyldithiocarbamate at a concentration of $0.01 \mathrm{mg} / \mathrm{g}$ wet for $48 \mathrm{hrs}$ in Carassius auratus caused significant decrease in activities of SOD, GST and increased CAT activity with significant increase in protein carbonyl levels in the brain, liver and kidney [56]. In the present study the reason for increased protein carbonyl level under the influence of methomyl treatment in mice may be due to increased level of ROS or oxidative stress.

In the present investigation there is significant decrease in the activity of CAT, SOD and GST in mouse liver by high dose and prolonged exposure of methomyl. It has been reported that SOD, CAT and GST constitute a mutually supportive team of defense against ROS $[57,58]$. CAT and SOD are known to play an important role in scavenging ROS. SOD catalyzes the destruction of the superoxide radicals. CAT is known to reduce the $\mathrm{H}_{2} \mathrm{O}_{2}$ into water and oxygen to prevent oxidative stress and in maintaining cell homeostasis. These activities have been reported to be an indicator of tissue's ability to cope with oxidative stress $[59,60]$. Thus an increase in SOD and CAT might be in response to increased oxidative stress. However, when a condition of oxidative stress strongly establishes, the defense capacities against ROS becomes insufficient [61], in turn ROS also affects the antioxidant defense mechanisms, reduces the intracellular concentration of GSH and decreases the activity of SOD and CAT. It has also been known to decrease the detoxification system produced by GST [62]. Increasing evidence indicates that oxidative stress causes organ injury and carcinogenesis [63].

GST is an enzyme, which is involved in the detoxification Process. An important function of GST in response to oxidative stress is its ability to conjugate GSH with lipid peroxidation products [64]. They conjugate substrate xenobiotics with utilization of reduced glutathione (GSH); the glutathione conjugates being more water soluble are easily eliminated from the body. In addition to conjugation reactions, some members of the GST superfamily can serve as peroxidases and isomerases [65]. They have been shown to be instrumental in protecting against electrophiles and products of oxidative stress [66]. It has been reported that carbamate fungicide carbendazim known to diminish activities of SOD, CAT, GST and markedly elevates LPO and ROS in Leydig cells of rats with the administration of $25 \mathrm{mg} / \mathrm{kg}$ body weight orally for 48 days [29]. In another study the carbamate pesticides both aldicarb and propoxur significantly inhibited activity of GST and increased level of TBARS in CHO-K1 cells with cell injury due to increased oxidative stress [67]. In this study, GST activity was significantly reduced by high dose and prolonged exposure of methomyl. In agreement with these results, Mansour et al found that methomyl decreased the activity of SOD, GST and increased LPO in rat erythrocytes [34]. According to Garg et al acute $24 \mathrm{hr}$ single oral dose of $9 \mathrm{mg} / \mathrm{kg}$ of methomyl treatment to rats resulted in a significant increase in the LPO, further GSH levels and the activities of Catalase and GST were found to be significantly decreased following methomyl treatment [68]. Similarly ElKhawaga found that methomyl decreased the activity of SOD, CAT and GST in mice liver [24], and Salama et al. (2005) reported that methomyl mode of action could be due to the induction of oxidative stress [69].

Histopathological studies revealed that increase in dose and durational exposure of methomyl caused cytoplasmic vacuolization, hyalization, dilated central vein with hypertrophy of hepatocytes with pycnotic nuclei and there is loss of radial arrangement of hepatocytes. Cell inflammatory response, resulting from cell swelling, loss of plasma membrane integrity and leakage of cellular contents into the extra cellular space is certainly be necrotic condition of liver cells[70, 71,72]. Recently similar effect was observed in female mouse with similar dose and durational exposure of methomyl [28]. Quest et al [73] reported that methyl carbamate causes focal hepatocellular necrosis, pigmentation of kupffer's cells with pycnotic nuclei in rats and mice. On the other hand thioacetamide which is derivative of methomyl also employed as pesticide and is well known hepatotoxin that cause centrilobular necrosis similar to carbon tetrachloride[73] and causes cell death via both apoptosis and necrosis in rat[75,76]. Similar histogical alterations have been reported in mouse on treatment with carbendazim and carbosulfan [35, 77].

Thus, the result of the present study suggests that chronic exposure to methomyl insecticide has deleterious effect on mouse liver. Therefore, application of such insecticide for designed program should be limited or special care should be taken to minimize its hazards.

\section{Acknowledgement}

The authors are grateful to the Post - Graduate Department of Studies in Biotechnology and Microbiology, Karnatak University, Dharwad for providing Necessary Facilities. 


\section{References}

[1] Green T., Toghill A., Lee R., Waechter F. Weber E., Peffer R., Noakes J. (2005) Toxicol Sci, 86: 36-47.

[2] Meister R.T. (1991) Farm Chemicals Handbook '91. Meister Publishing Company, Willoughby, Ohio.

[3] Baron R. L. (1991) Carbamate insecticides, In Handbook of Pesticide Toxicology Vol 3, Hayes WJ., Laws E.R. (Eds). San Diego, Calif, Academic Press, New York. pp 1125-90.

[4] EPA. (1996) Drinking Water Regulations and Health Advisories,USEPA, 822-B-96002, Washington, DC.

[5] Wei L.Y., Chao J. S., Hong C. C. (1997) Environ Mol Mutagen, 29(4): 386-93.

[6] Andersen H.R., Vinggaard A.M. Rasmussen T.H. (2002) Toxicol Appl Pharmacol, 179: 1-12.

[7] Romero P., Barnett P.G., Midthing J.E. (1989) Environ Res, 50 (2): 256-261.

[8] Tsai M.J., Wu S.N., Cheng H.A., Wang S.H., Chiang H.T. (2003) J Toxicol Clin Toxicol, 41 (7): 969-3.

[9] Moriya F., Hoshimoto Y. (2005) Forensic sci Int, 149(2 -3): 167-170.

[10] Agha A., Dib S., Al-Hakami M., Abdulhadi Ali M. (2009) The Intrnet Jrnl of Toxicol, 7:1.

[11] Ellman G. (1959) Arch Biochem Biophys, 82: 70-73.

[12] Roe J.H., Kuether C.A. (1942) Science, 95: 77.

[13] Okhawa. H., Ohisi N., Yagi N. (1979) Ann Biochem, 5: 351-358.

[14] Levine R.L., Garland D., Oliver C.N., Amisi A., Climent I., Lenz A., Ahn B., Shaltiel S., Stadtman E. Methods Enzymol, 186: 464478.

[15] Aebi H. (1974) Chemic Academic press Inc. Verlag, NY. 2: 673-85

[16] Kakker P., Das B., Vishwanathan P.N. (1984) Ind J Biochem Biophys, 21: 13032.

[17] Habig W.H., Jokoby W.B. (1974) J Biol Chem, 249: 7130-7139.

[18] Lowry H., Rosebrough N.I., Far A.L., Randall R.J. (1951) J Biol Chem, 193: 265- 275.

[19] Mitchell J.R., Jollows D.J. (1975) Gastroenterology, 68: 392-410.

[20] Wang X., Kanel G.C., DeLeve L.D. (2000) Hepatolog, 31: 428-434.

[21] Scholz R.W., Reddy P.W., Wynn M.K., Graham K.S., Liken A.D., Gumpricht E., Reddy C.C. (1997) Free Radic Biol Med, 23: 815-828.

[22] Bouchard G., Yousef I.M., Barriault C., Tuchweber B. (2000) J Hepatol, 32: 550560.

[23] Banerjee B.D., Seth V.,Bhattacharya A. (1999). Toxicol Lett, 107: 33-47.

[24] El-Khawaga O.A. (2005) J Physiol Biochem, 61(4): 501-506.
[25] Sharma R.K., Agarwal A. (1996) Urology, 48: 835-50.

[26] Sanz N., Diez-Fernandez C., Andres D., Cascales M. (2002) Biochim Biophys Acta, 1587: 12-20.

[27] Manawadi S. I., Kaliwal B. B. (2009) Int jrnl of biotech res (suppl), 2(1): 8-16.

[28] Manawadi S. I., Kaliwal B. B. (2009) Ind. Jrnl of comp Anim physiol, 27(2): 106-112.

[29] Rajeswary S., Kumaran B., llangovan R., Yuvaraj S., Sridhar M., Venkataraman P., Srinivasan N., Aruldhas M.M. (2007) Reprod Toxicol, 24(3-4): 371-80.

[30] Frei B., England L., Ames B. N., Thorburn D., Curry G., Spooner R., Spence E., Oien K., Halls D., Fox, R., McCruden E. A., MacSween R. N. \& Mills P. R. (1989) Proc. Natl. Acad. Sci, U.S.A. 86: 63776381.

[31] Barja G., Lopez-Torres M., Perez-Campo R., Rojas C., Cadenas S., Prat J., Pamplona R. (1994) Free Radic. Biol. Med, 17: 105-115.

[32] Brown L. A., Harris F. L. Jones D. P. (1997) Am. J. Physiol, 273: L782-L788.

[33] Maeda N., Hagihara H., Nakata Y., Hiller S., Wilder J. Reddick R. (2000) Proc. Natl. Acad. Sci, U.S.A. 97: 841-846.

[34] Mansour S.A., Mossa A. H., Heikal T. M. (2009) Toxicol Ind Health, 25: 557.

[35] Ksheerasagar R.L., Kaliwal B.B. (2006) Caspian J Env Sci, 4(1): 61-70.

[36] Shefer S.,Hauser S., Mosbach E.H. (1968) J.Lipid Res, 9: 328.

[37] Hemila H. (1992) Crit Rev Food Sci Nutr 32: 33-37.

[38] Holloway D.E., Rivers J.M. (1984) J Nutr, 114: 1370-1376.

[39] Ginter E. (1972) Vopr. Pitaniia, 31: 25(in Russian).

[40] Krumdieck C., Butterworth C.E. (1974) Amer.J. Clin. Nutr, 27: 866.

[41] Debnath D., Mandal T.K. (2000) J Appl Toxicol, 20: 197-204.

[42] Osman K.A. (1999) J Agric Res, 44: 345355.

[43] Salama A.K., Osman K.A., Aly N.M. (2001) Toxicology, 164: 193-194.

[44] Abdollahi M., Mostafalou S. Pournourmohammadi S., Shadnia S. (2004) Comp. Biochem. Physiol. C, 137: 29-34.

[45] Yarsan E., Tanyuksel M., Celik S., Aydin A. (1999) Bull.Environ.Contam.Toxicol, 63(5): 575-581.

[46] Yarsan E., Bilgili A., Kanbur M., Celik S. (2002) Vet. Hum. Toxicol, 44: 73-75.

[47] Seth V., Banerjee B. D., Bhattacharya A., Chakravorty A.K. (2000) Clin. Biochem, 33: 683-685.

[48] Zama D., Meraihi Z., Tebibel S., Benayssa W., Benayache F., Benayache S., Vlietinck A.J. (2007) Indian J Pharmacol, 39(3): 145-150.

[49] Ong C.N., Shen H.M., Chia S.E. (2002) Toxicol Lett, 134: 17-30. 
[50] Choy C. S., Cheah K. P., Chiou H. Y., Li J. S., Liu Y. H., Yong S. F., Chiu W. T., Liao J. W., Hu C. M. (2008) J. Appl. Toxicol, 10: $1002-1010$.

[51] Fagan J. M., Sleczka B. G., Sohar I. (1999) Int. J. Biochem. Cell Biol, 31: 751-757.

[52] Zusterzeel P.L., Mulder T.P., Peters W.H., Wiseman S.A., Steegers E.A. (2000) Free Radic Res, 33(5): 471-476.

[53] Stadtman E.R., Berlett B.S. (1998) Drug Metab Rev, 30: 225-243.

[54] Zimmerman L.J., Valentine H.L., Valentine W.M. (2004) Chem Res Toxicol, 17(2): 258-67.

[55] Hatcher J.M., Richardson J.R., Guillot T.S., McCormack A.L., Di Monte D.A., Jones D.P., Pennell K.D., Miller G.W. (2007) Experi Neurol, 204: 619-630.

[56] Lushchak V.I., Bagnyukova T.V., Lushchak O.V., Storey J.M., Storey K.B. (2007) Chem Biol Interac, 20: 170 (1): 1-8.

[57] Bandhopadhy U., Das D., Banerjee K.R. (1999) Curr Sci, 77: 658-665.

[58] Tabatabaie T., Floyd R.A. (1994) Arch Biochem Biophys, 314: 112-119.

[59] Mimic-Oka J., Simic T., Djukanovic L., Reljic Z., Davicevic Z. (1999) Clin Nephrol, 51:233-241.

[60] Husain K., Somani S.M. (1997) J Appl Toxicol, 17: 189-194.

[61] Halliwell B., Gutteridge J.M. (2000) Free radicals in Biology and medicine, Oxford University Press, 148-149.

[62] Yamamoto Y., Yamashita S. (1999) BioFactors, 9: 241-245.

[63] Stal P., Olson J. (2000) Ubiquinone: Edited by: Kagan Ve, Quinn DJ. CRC Press, Boca Raton, 317-329.
[64] Rao A.V. and Shaha C. (2000) Free Radic. Biol. Med, 29: 1015-1027.

[65] Mannervik B., Danielson U. H. (1988) CRC Crit. Rev. Biochem, 23: 283-337.

[66] Hayes J. D., Flanagan J. U., Jowsey I. R. (2005) Annu. Rev. Pharmacol. Toxicol, 45: 51-88.

[67] Maran E., Fernandez-Franzon M., Font G. Ruiz M.J. (2010) Food Chem Toxicol, 48(6):1592-6.

[68] Garg D.P., Kiran R., Bansal A.K., Malhotra A., Dhawan D.K. (2008) Drug Chem Toxicol, 31(4): 487-99.

[69] Salama A.K., Osman K.A., Saber N.A., Soliman S.A. (2005) Pak Jrnl of Biol Scices, 8: 92-96.

[70] Yoon J.Y., Oh S.H., Yoo S.M., Lee S.J., Lee H.S., Choi S.J., Moon C.K., Lee B.H. (2001) Toxicolog, 169: 153-161.

[71] Raffray M., Cohen G.M. (1997) Pharmacol Ther, 75: 153-177.

[72] Wyllie A.H. (1980) Nature, 284: 555-556.

[73] Quest J.A., Chan P.C., Crawford D., Kanagalingam K.K., Hall W.C. (1987) Fundam Appl Toxicol, 8(3): 389-99.

[74] Mario L.A., Chiu H., Sprowles K.A., Zhou P., Heck D.E. (2001) Toxicol Appl Pharmacol, 172: 44-51.

[75] Landon E.J., Naukam R.J., Rama Sastry B.V. (1986) Biochem Pharmacol, 35: 697705.

[76] Diez-fernandez C., Bosca L., Fernandezsimon L., Alvarez A., Cascales M. (1993) Hepatology, 18: 912-918.

[77] McCarrol N.E., Protzel A., loannou Y., Frank Stack H.F., Jackson M.A., Waters M.D., Dearfield K.L. (2002) Mutat Res, 512(1): 1-35. 


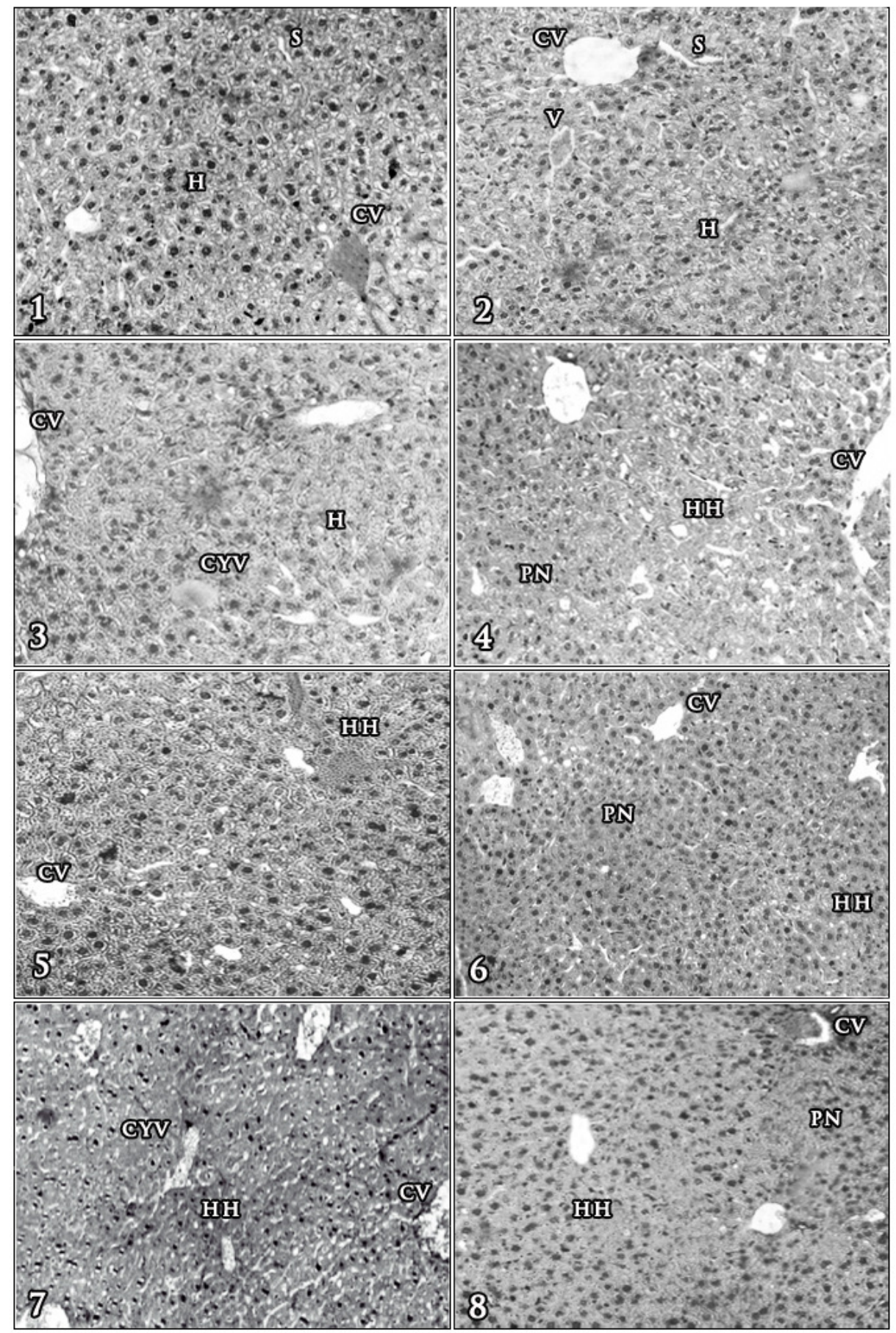

Fig.1. T.S. of the liver of the control mouse showing radially arranged hepatic cords around the central vein and normal hepatocytes with centrally located nuclei. 
Fig.2. T.S. of the liver of the mouse treated with $1 \mathrm{mg} / \mathrm{kg} /$ day methomyl for 30 days showing dilated central vein with hypertrophy of hepatocytes. Radial arrangement of hepatocytes is lossed.

Fig.3. T.S. of the liver of the mouse treated with $2 \mathrm{mg} / \mathrm{kg} /$ day methomyl for 30 days showing hypertrophy of hepatocytes with pyknotic nuclei, vacuoles and cytoplasmic vacuolization. Radial arrangement of hepatocytes is lossed.

Fig.4. T.S. of the liver of the mouse treated with $3 \mathrm{mg} / \mathrm{kg} /$ day methomyl for 30 days showing dilation of central vein, hypertrophied hepatocytes with pyknotic nuclei and hyalinization of hepatocytes with loss of radial arrangement.

Fig.5. T.S. of the liver of the mouse treated with $4 \mathrm{mg} / \mathrm{kg} /$ day methomyl for 5 days showing hypertrophy and hyalinization of hepatocytes with dilated central vein.

Fig.6. T.S. of the liver of the mouse treated with $4 \mathrm{mg} / \mathrm{kg} /$ day methomyl for 10 days showing dilation of central vein, hypertrophy of hepatocytes with pyknotic nuclei, vacuoles and hyalinization. Radial arrangement of hepatocytes lossed.

Fig.7. T.S. of the liver of the mouse treated with $4 \mathrm{mg} / \mathrm{kg} /$ day methomyl for 20 days showing vacuolization, hypertrophy, cytoplasmic vacuolization and loss of radial arrangement of hepatocytes.

Fig.8. T.S. of the liver of the mouse treated with $4 \mathrm{mg} / \mathrm{kg} /$ day methomyl for 30 days showing vacuolization, hypertrophy and hyalinization of hepatocytes with dilation of central vein. Radial arrangement of hepatocytes is lossed.

Photographs original exposure at X 100 .

V-Vacuoles CV-Central Vein HH-Hypertrophied Hepatocytes

PN-Pyknotic nuclei CYV -cytoplasmic vacuolization S-Sinusoids 
Table 1- Effect of methomyl on liver oxidative stress parameters in male mice

\begin{tabular}{|c|c|c|c|c|c|c|c|}
\hline \multirow{2}{*}{ Treatment } & \multicolumn{2}{|c|}{ Antioxidants } & \multicolumn{2}{|c|}{$\begin{array}{l}\text { Oxidative stress } \\
\text { byproducts }\end{array}$} & \multicolumn{3}{|c|}{ Oxidative stress enzymes } \\
\hline & $\mathrm{GSH}^{\mathrm{a}}$ & $\begin{array}{l}\text { Ascorbic } \\
\text { acid }^{b}\end{array}$ & TBARS $^{c}$ & $\begin{array}{l}\text { Protein } \\
\text { carbonyl d }\end{array}$ & Catalase & $\operatorname{SOD}^{f}$ & GST $^{\mathrm{g}}$ \\
\hline Control & $10.70 \pm 0.10$ & $422 \pm 0.25$ & $0.24 \pm 0.15$ & $1.32 \pm 0.06$ & $165 \pm 0.10$ & $48.5 \pm 0.25$ & $4.8 \pm 0.04$ \\
\hline $1 \mathrm{mg} / \mathrm{kg} / \mathrm{d}$ & $10.65 \pm 0.12$ & $418 \pm 0.42$ & $0.28 \pm 0.12$ & $1.35 \pm 0.12$ & $164 \pm 0.12$ & $48.2 \pm 0.30$ & $4.7 \pm 0.05$ \\
\hline $2 \mathrm{mg} / \mathrm{kg} / \mathrm{d}$ & $9.44 \pm 0.14^{*}$ & $410 \pm 0.50$ & $0.31 \pm 0.12$ & $1.40 \pm 0.06^{*}$ & $158 \pm 0.18$ & $40.7 \pm 0.10^{*}$ & $4.0 \pm 0.02^{*}$ \\
\hline $3 \mathrm{mg} / \mathrm{kg} / \mathrm{d}$ & $8.72 \pm 0.05^{\star}$ & $354 \pm 0.32^{*}$ & $0.42 \pm 0.20^{*}$ & $1.55 \pm 0.08^{*}$ & $150 \pm 0.10$ & $36.2 \pm 0.16^{\star}$ & $3.3 \pm 0.04^{*}$ \\
\hline $4 \mathrm{mg} / \mathrm{kg} / \mathrm{d}$ & $7.80 \pm 0.05^{\star}$ & $330 \pm 0.30^{*}$ & $0.50 \pm 0.18^{\star}$ & $1.65 \pm 0.04^{*}$ & $\begin{array}{ll}135 & \pm \\
0.13^{*} & \\
\end{array}$ & $32.4 \pm 0.15^{\star}$ & $2.9 \pm 0.02^{*}$ \\
\hline 5 days & $10.62 \pm 0.06$ & $420 \pm 0.32$ & $0.28 \pm 0.10$ & $1.36 \pm 0.06$ & $163 \pm 0.20$ & $47.9 \pm 0.20$ & $4.7 \pm 0.04$ \\
\hline 10 days & $9.50 \pm 0.20^{*}$ & $380 \pm 0.40^{*}$ & $0.34 \pm 0.16^{*}$ & $1.42 \pm 0.10^{*}$ & $159 \pm 0.28$ & $41.8 \pm 0.12^{*}$ & $3.8 \pm 0.06^{*}$ \\
\hline 20 days & $8.66 \pm 0.05^{\star}$ & $354 \pm 0.28^{*}$ & $0.42 \pm 0.14^{*}$ & $1.58 \pm 0.07^{\star}$ & $148 \pm 0.15$ & $35.6 \pm 0.10^{*}$ & $3.4 \pm 0.07^{*}$ \\
\hline \multicolumn{8}{|c|}{$\begin{array}{l}\text { a } \mu \mathrm{mol} \text { of } \mathrm{GSH} / \mathrm{mg} \text { protein } \\
\mathbf{b} \mu \mathrm{mol} \text { of ascorbic acid/gm wet tissue } \\
\text { c nmoles MDA } / \mathrm{mg} \text { of tissue protein } \\
\text { d nmoles of protein carbonyl/mg protein } \\
\text { Values are mean } \pm \text { SEM of } 10 \text { animals. }\end{array}$} \\
\hline
\end{tabular}

